\title{
COVID-19 pandemic: rapid survey on social and mobility impact in Algerian cities
}

\author{
Saad Eddine Boutebal ${ }^{1} \cdot$ Azzeddine Madani $^{1,2}$ (I) $\cdot$ Christopher Robin Bryant $^{3}$
}

Received: 23 July 2020 / Accepted: 3 December 2020 / Published online: 7 January 2021

(C) Springer-Verlag GmbH Germany, part of Springer Nature 2021

\begin{abstract}
Aims The impacts of the COVID-19 pandemic were very significant on the population following the application of total and partial confinement measures. Our study aimed to investigate the social and mobility impact of confinement on the Algerian population using a cross-sectional survey launched after 3 days of the start of confinement to quickly assess the impacts during the period of March 23 to April 12, 2020.

Subject and methods We used an online questionnaire to obtain 678 responses from internet users, who were living in confinement in Algeria. According to the gender variable, our sample included 405 men (59.7\%) and 273 women (40.3\%).

Results The statistical analysis performed showed that road interactions and mobility are only part of the social interactions, and that $95.1 \%$ of the respondents avoided family visits during these first 3 weeks of confinement. Of respondents, $85.5 \%$ spend a considerable amount of time chatting with family, $66.6 \%$ found the diet beneficial during this period, $57 \%$ participated in sports to preserve their health, $87.2 \%$ of respondents respected the travel ban, only $20.2 \%$ of those surveyed used a bicycle for travel, and $55.9 \%$ traveled on foot to go shopping.

Conclusion The study also showed significant impacts on the social aspects linked to travel, namely family relationships and sports activities, as well as significant impacts on the mobility of people.
\end{abstract}

Keywords Epidemic $\cdot$ Public health $\cdot$ Social impact $\cdot$ Mobility impact $\cdot$ COVID-19 $\cdot$ Algeria cities

\section{Introduction}

The coronavirus disease (COVID-19) pandemic has spread rapidly in countries worldwide. The number of people who tested positive reached 2,397,217 in several countries, which also recorded 162,956 deaths as of April 21, 2020 (Who 2020). In China, COVID-19 spread rapidly since its first

Azzeddine Madani

Saad Eddine Boutebal

s.boutebal@univ-dbkm.dz

Christopher Robin Bryant

christopher.robin.bryant@gmail.com

1 Faculty of Social and Human Sciences, Khemis Miliana University, Khemis Miliana, Algeria

2 Cité fréres Embarek, 162, Ain Defla 44000, Algeria

3 Department of Geography, University of Montréal, Montréal, Canada appearance in Wuhan and has proven to be very dangerous because some affected patients do not have fever and other symptoms, which complicates the diagnosis (Guan et al. 2020). The report of the National Health Commission of China indicated on January 27, 2020, that people with the virus can infect others through respiratory droplets and also through direct contact (Fan et al. 2020). The severity of the disease is summed up in the ability of the virus to spread and the difficulties in identifying those affected to manage them and prevent them from infecting others (Munster et al. 2020). Faced with this situation, the Chinese government reacted quickly by quarantining a population estimated at 50 million people, with total closure imposed on Wuhan on January 23, 2020 , in order to establish a total social distancing, which forced citizens to stay at home to protect them from the virus (Wang et al. 2020), and to prevent the spread of the epidemic to other parts of China. The consequences of the total confinement of the population certainly has effects on the economies of countries and on the mental health of people, as well as their habits and mobility. Psychological effects are increased, and fear seems an almost certain consequence because of this way 
of life, and anxiety was expected in Wuhan and could increase each time death increased and information on new cases circulated (Rubin and Wessely 2020). It has been found that the international response to COVID-19 is more transparent and effective compared to the SARS epidemic (Sohrabi et al. 2020), which will allow countries to build on actions already taken.

Algeria, a country very close to Europe and located in northern Africa, has been affected by the pandemic. Its first recorded case dates from February 25, 2020. Table 1 shows the evolution of the number of infected people reached 2811, according to the monitoring cell of the Algerian Ministry of Health, Population and Hospital Reform (MSPRH), which also recorded 392 deaths on April 21, 2020 (MSPRH 2020a). This pandemic has shown the lack of preparation of several European countries and the slow nature of decision-making processes (Bailly 2020).

This situation was also noted in countries of Africa, including in Algeria, which took a rather late decision to isolate the region of Blida - the most affected at the beginning of the epidemic - thus facilitating the spread of the virus (Madani 2020). Subsequently, other decisions were taken by the Algerian government, also within the framework of social distancing. The Algerian population thus found themselves in a new way of life imposed by total or partial confinement. This social distancing certainly has influenced several aspects, including the mental health of patients, healthy people, and medical personnel. It has been shown in previous research, for instance, that when dealing with the psychosocial effects of the Ebola epidemic (Van Bortel et al. 2016), the magnitude of the psychosocial effects on individuals and society even at the international level became apparent during the onset of the epidemic. In Algeria, from March 23, 2020, for more than a month, the population lived in partial or total confinement, which lengthened further and revealed questions linked to the nature of the correlation between age, the social impact, and mobility during the first 3 weeks of confinement in Algeria, as well as the impact of confinement on society, daily life, and the mobility of citizens.

We also want to answer questions about the difference in social impact of COVID-19 according to the gender variable and the impact of this virus on mobility according to the same variable. We will also shed light on the impact of confinement on the social aspect and that of mobility according to the family situation. The application of confinement is considered essential, but can cause a slowdown in life and sometimes blockages that can lead to significant psychological and psychiatric disorders marked by depression, panic disorders, and behavioral disorders (Sood 2020) as well as disruptions in mobility and in reactions within society.

Currently, there is no detailed information on the impact of total and partial confinement, during this period of the COVID-19 epidemic, on the Algerian population from the point of view of social impact and mobility. Our study was launched after only 3 days of the establishment of this method of disease containment in Algeria. The study's objectives are to discover the impact of confinement on society and mobility in Algeria and to study the nature of the correlation between the elderly, social impact, and mobility during the first confinement linked to COVID-19. The design of a questionnaire to measure the impact of confinement on society and mobility as well as the identification of the main social factors and mobility during this confinement with regard to gender and family situation are also part of the objectives of this study, which will be able to help the Algerian authorities and possibly other countries to take adequate measures to better take care of the population during the COVID-19 pandemic.

Containment procedures involving partial or total confinement were approved by the Algerian state on March 23, 2020 to combat the COVID-19 pandemic. The social impacts encompass the various social effects of confinement in Algeria on the social interactions of daily life, including on the impact of mobility, which represents the totality of the behaviors of road users and all road interactions, both measured in the current study by the sum of the responses from the questionnaire according to the respondents in the sample.

The present study is limited by its subject, which was to study mobility and the social impact of confinement during the COVID-19 pandemic in Algeria using a questionnaire to measure these factors. This study is also limited by its actual sample of questionnaire respondents, and the short duration of the study from March 23 to April 12, 2020, imposed by the exceptional nature of this confinement and this epiedemic.
Table 1 The weekly evolution of the COVID-19 epidemic in Algeria during the period from March 23 to April 13, 2020

\begin{tabular}{lllll}
\hline Date & New infected per day & Total infected & News deaths/day & Total deaths \\
\hline March 23 & 29 & 230 & 0 & 17 \\
March 30 & 73 & 584 & 4 & 35 \\
April 7 & 45 & 1468 & 20 & 193 \\
April 14 & 97 & 2070 & 13 & 326 \\
April 21 & 93 & 2811 & 8 & 392 \\
\hline
\end{tabular}

Source: the authors based on the data (MSPRH 2020b) 


\section{Materials and methods}

A transversal survey plan is used to study the social and mobility impacts during the COVID-19 epidemic on citizens in Algeria. Thus, the descriptive method was used in this study because it corresponds with the nature of the study related to these kinds of impacts of the pandemic. We adopted a crosssectional survey to assess the immediate social and mobility impact on the public during the COVID-19 epidemic using an online questionnaire that was widely disseminated with the help of university students, and our sampling strategy based on the snowball method is suitable in exceptional cases where it is difficult to communicate with the population to study an urgent health problem related to confinement. Therefore, the sample of the current study is made up of 678 Algerian internet users, who lived in Algeria during the first confinement of the coronavirus disease (COVID-19) epidemic. According to the gender variable, our sample includes 273 women representing $40.3 \%$ and 405 men representing $59.7 \%$. For the age variable, 423 people were aged between 14 and 34 years old or $62.4 \%, 239$ people were aged between 35 and 54 years old or $35.2 \%$ and 16 people were aged between 55 and 74 years old or $2.4 \%$ of the total size of the sample. Therefore, we see in the composition of this sample the representation of practically all the age groups of the society concerned by this research issue. The impact of COVID-19 confinement was measured using a global questionnaire. This questionnaire is composed of two subscales: social impact and impact on mobility. The Coronavirus Impact Scale COVID19 in Algeria was designed according to the standards of the Likert scale and includes five response options, as we show in the following:

\begin{tabular}{lllll}
\hline Not agree at all & Disagree & Neutral & Agreed & Totally agree \\
1 & 2 & 3 & 4 & 5 \\
\hline
\end{tabular}

This means that the average score for the questionnaire items is (3); therefore, a total score greater than three indicates a negative impact on this variable, and when it is less than 3 , it means that there has not been a negative impact within the meaning of this element. The questionnaire was designed online to facilitate its dissemination and immediately obtain the respondents' answers. The social impact contains (12) elements, meaning that the total score varies from 60 to 12 with a theoretical average of 36 , and it also means that a score exceeding 36 reflects a considerable effect on the social factor. In addition, the dimension of the impact of mobility contains (07) items, meaning that the total score varies from 07 to 35 with a theoretical average of 21 , and it also means that a score exceeding 21 reflects a considerable effect on factor mobility.
To ensure that the coronavirus confinement impact questionnaire regarding COVID-19 would likely produce the same results for all recurrent measures, whether within the same or a similar population, reliability testing is essential. Thus, we used Cronbach's alpha coefficient of dimensions-social impact (0.799) and mobility impact (0.613) - to ensure that the questionnaire will produce stable and reliable results. In addition, the internal validity of the questionnaire was confirmed, with all the correlation coefficients between the items and the score of the corresponding dimension being positive and statistically significant. This increases confidence in the results of the questionnaire. Data were entered into the computer using SPSS 22 software. Results are presented in tables, and data were collected using descriptive statistics, including frequencies, relative weights, means, and deviations that were calculated to summarize the responses to the items in the questionnaire on social impact and mobility during the confinement because of COVID-19. In addition, the questions in our study were analyzed by applying several statistical equations such as the Pearson correlation coefficient to measure the relationship between age and social impact and mobility. In addition, the T-test was used for the independent sample to study social impact and mobility related to coronavirus confinement by gender and family situation.

\section{Results}

\section{The correlation between age and social and mobility impact during the first confinement of the epidemic}

Table 2 shows the presence of a statistically significant positive correlation between the social effects variable and the effects on mobility and transport $(r=0.229)$, with an error level equal to (0.01), and this result means that road interactions and mobility are only part of the social interactions in daily life.

Table 2 The correlation matrix between age and social impact and mobility during the first confinement of the coronavirus disease (COVID-19) epidemic in Algeria

\begin{tabular}{llll}
\hline Variables & Age & Social impact & Impact mobility \\
\hline Age & $\mathbf{1}$ & $\mathbf{0 . 0 4 6}$ & $\mathbf{0 . 0 3 2}$ \\
Social impact & $\mathbf{0 . 0 4 6}$ & $\mathbf{1}$ & $\mathbf{0 . 2 2 9}$ \\
Impact mobility & $\mathbf{0 . 0 3 2}$ & $\mathbf{0 . 2 2 9 * *}$ & $\mathbf{1}$ \\
\hline
\end{tabular}

**The correlation is significant at the 0.01 level (bilateral) 


\section{The social impact of the confinement because of the COVID-19 epidemic on the daily life of Algerian citizens}

The results in Table 3 indicate that the item related to the avoidance of family visits is ranked first with a relative weight of $92.40 \%$ and an $M=4.62$. This result is explained by a strong social awareness that direct social communication should be avoided due to the nature of transmission of COVID-19 infection. The refusal to attend funerals has a relative weight of $85.60 \%$ and $M=4.28$, which also shows the awareness of the danger of traveling for the funeral, especially if they occur due to a coronavirus infection. Family dialogue ranks third with a relative weight of $82.00 \%$ and $\mathrm{M}=4.10$. This means that the Algerian family had a high rate of dialogue during the confinement period, and this is justified by the significant interaction of family members during the day. In fourth place, we find the use of smartphones as the best way to pass the time during the period of confinement with a relative weight of $78.00 \%$ and $\mathrm{M}=3.90$. This indicates that people prefer the use of smartphones that contain programs and applications allowing remote social communication and offer the possibility of watching various videos and news according to the wishes of the individual, as a way to spend time.

We find in fifth place the diet is beneficial during the confinement period with a relative weight of $75.80 \%$ and $\mathrm{M}=$ 3.79. Admittedly, dieting is a necessity, according to the members of the sample, because movements and activities outside are almost stopped due to home confinement. Control of children during confinement, according to the results in Table 3, are at a relative weight of $73.00 \%$ and $\mathrm{M}=3.65$. This means that families complained about the difficulty of controlling the children and organizing interactions inside the house, especially with the children's usual desire to move. In the seventh row, we find the ease of buying what is necessary for daily life, with a relative weight of $70.40 \%$ and $M=3.52$. This means that there is a person in charge of shopping on a regular basis, which makes it easier to comply with home confinement instructions. The practice of sports at home in confinement is in eighth place with a relative weight of $68.20 \%$ and $M=3.41$. This indicates that the study sample prefers to participate in sports activities in the home during the confinement period because of movement restrictions. In ninth place, we find the difficulty of organizing fun games for children at home during the confinement period, with a relative weight of $67.80 \%$ and $M=3.39$. Admittedly, the organization of renewable and changing games throughout the day and during the days of confinement is an important challenge for parents, and this is what makes them live under pressure because of their desire to put in place a comfortable family climate for their children. In addition, communication with family members according to the instructions for the preventive distance has a relative weight of $65.20 \%$ and $M=3.26$. This indicates compliance with the instructions to prevent coronavirus, even with family members, especially those who go out frequently, because they can infect family members. The item of difficulty in staying at home is in the eleventh position with a relative weight of $65.00 \%$ and $M=3.25$. Admittedly, there is confirmation of the slight difficulty in respecting home confinement, but the seriousness of the coronavirus requires caution and staying at home. In last position, we find the effects of the limited space in the house during the confinement period, with a relative weight of $61.00 \%$ and $M=3.05$; therefore, the limited space of the house negatively affects the commitment to home confinement, especially for large families.

\section{The impact of mobility on Algerian citizens during the confinement because of the COVID-19 epidemic}

The results in Table 4 show that the item related to compliance with the ban on movement at night during confinement is ranked first with a relative weight of $86.60 \%$ and $\mathrm{M}=4.33$. This result is explained by a significant commitment not to move at night among the members of the study sample; and using the procedures of confinement at home. In second position is the movement on foot during the confinement period with a relative weight of $65.60 \%$ and $M=3.28$. Thus, many people prefer to walk for a short time to buy products and go home. In third place, there is the availability of individual means of transport during confinement with a relative weight of $(61.20 \%)$ and $(M=3.06)$, since during the confinement period, it is permissible to use means of individual transport. The ease of moving during the confinement period with a relative weight of $58.60 \%$ and $\mathrm{M}=2.93$ is placed in fourth position. This shows the difficulty of movement due to strict control of the movements of the citizens to make them aware of the need to respect containment procedures during the coronavirus pandemic COVID-19 in order to protect themselves.

In terms of preferring to use a bike to move around during confinement, this item is placed in fifth place with a relative weight of $53.60 \%$ and $M=2.68$. This result reflects the reduced use of bicycles when traveling, which also applies to the normal situation due to the lack of a road strategy to develop a safe environment for cyclists. We find in the seventh position, the availability of the minimum transport service during the confinement period with a relative weight of $49.80 \%$ and $M=2.4$ because all public transport was stopped for fear that it would intensify the spread of the coronavirus. In the last position, we find the displacement for the purchase of the necessary things during confinement with a relative weight of $49.20 \%$ and $\mathrm{M}=2.46$. This indicates the ease of purchasing various needed supplies without having to travel extensively, which helps to keep confinement in check. 
Table 3 Descriptive statistics of the social impact of COVID-19 during the first confinement of the epidemic in Algeria $(n=678)$

\begin{tabular}{|c|c|c|c|c|c|c|}
\hline \multirow[t]{2}{*}{ Items } & \multicolumn{3}{|l|}{$\mathrm{N}=678$} & \multirow[t]{2}{*}{ Mean (M) } & \multirow[t]{2}{*}{ Relative weight } & \multirow[t]{2}{*}{ Rating } \\
\hline & & $\mathrm{n}$ & $\%$ & & & \\
\hline \multirow[t]{5}{*}{ I find it difficult to stay in home confinement } & Not agree at all & 95 & 14.0 & \multirow[t]{5}{*}{3.25} & \multirow[t]{5}{*}{65.00} & \multirow[t]{5}{*}{11} \\
\hline & Disagree & 134 & 19.8 & & & \\
\hline & Neutral & 94 & 13.9 & & & \\
\hline & Agreed & 215 & 31.7 & & & \\
\hline & Totally agree & 140 & 20.6 & & & \\
\hline \multirow[t]{5}{*}{ Controlling children is difficult during confinement } & Not agree at all & 29 & 4.3 & \multirow[t]{5}{*}{3.65} & \multirow[t]{5}{*}{73.00} & \multirow[t]{5}{*}{06} \\
\hline & Disagree & 79 & 11.7 & & & \\
\hline & Neutral & 158 & 23.3 & & & \\
\hline & Agreed & 248 & 36.6 & & & \\
\hline & Totally agree & 164 & 24.1 & & & \\
\hline \multirow{5}{*}{$\begin{array}{l}\text { In confinement, I communicate with my } \\
\text { family members according to the } \\
\text { instructions of the preventive distance }\end{array}$} & Not agree at all & 69 & 10.2 & \multirow[t]{5}{*}{3.26} & 65.20 & 10 \\
\hline & Disagree & 127 & 18.7 & & & \\
\hline & Neutral & 157 & 23.2 & & & \\
\hline & Agreed & 210 & 31.0 & & & \\
\hline & Totally agree & 115 & 16.9 & & & \\
\hline We avoid family visits & Not agree at all & 0 & 0 & 4.62 & 92.40 & 01 \\
\hline & Disagree & 6 & 0.9 & & & \\
\hline & Neutral & 27 & 4.0 & & & \\
\hline & Agreed & 188 & 27.7 & & & \\
\hline & Totally agree & 457 & 67.4 & & & \\
\hline In confinement, I refuse to attend a funeral & Not agree at all & 14 & 2.1 & 4.28 & 85.60 & 02 \\
\hline & Disagree & 40 & 5.9 & & & \\
\hline & Neutral & 78 & 11.5 & & & \\
\hline & Agreed & 158 & 23.3 & & & \\
\hline & Totally agree & 388 & 57.2 & & & \\
\hline I find it easy to buy what I need in my daily life & Not agree at all & 44 & 6.5 & 3.52 & 70.40 & 07 \\
\hline & Disagree & 122 & 18.0 & & & \\
\hline & Neutral & 83 & 12.2 & & & \\
\hline & Agreed & 294 & 43.4 & & & \\
\hline & Totally agree & 135 & 19.9 & & & \\
\hline In confinement, I play sports at home & Not agree at all & 56 & 8.3 & 3.41 & 68.20 & 08 \\
\hline & Disagree & 111 & 16.4 & & & \\
\hline & Neutral & 138 & 20.4 & & & \\
\hline & Agreed & 248 & 36.6 & & & \\
\hline & Totally agree & 125 & 18.4 & & & \\
\hline I find that the diet is beneficial & Not agree at all & 27 & 4.0 & 3.79 & 75.80 & 05 \\
\hline during the period of confinement & Disagree & 56 & 8.3 & & & \\
\hline & Neutral & 144 & 21.2 & & & \\
\hline & Agreed & 254 & 37.5 & & & \\
\hline & Totally agree & 197 & 29.1 & & & \\
\hline Family dialogue prevails at & Not agree at all & 18 & 2.7 & 4.10 & 82.00 & 03 \\
\hline home during the confinement period & Disagree & 23 & 3.4 & & & \\
\hline & Neutral & 57 & 8.4 & & & \\
\hline & Agreed & 352 & 51.9 & & & \\
\hline & Totally agree & 228 & 33.6 & & & \\
\hline Limited space in the house bothers & Not agree at all & 89 & 13.1 & 3.05 & 61.00 & 12 \\
\hline me during the confinement period & Disagree & 178 & 26.3 & & & \\
\hline & Neutral & 132 & 19.5 & & & \\
\hline & Agreed & 167 & 24.6 & & & \\
\hline & Totally agree & 112 & 16.5 & & & \\
\hline It is difficult to organize fun games $\mathrm{f}$ & Not agree at all & 45 & 6.6 & 3.39 & 67.80 & 9 \\
\hline or children at home during the confinement period & Disagree & 89 & 13.1 & & & \\
\hline & Neutral & 232 & 34.2 & & & \\
\hline & Agreed & 183 & 27.0 & & & \\
\hline & Totally agree & 129 & 19.0 & & & \\
\hline Using smartphones is the best way $\mathrm{t}$ & Not agree at all & 27 & 4.0 & 3.90 & 78.00 & 04 \\
\hline o pass the time during the confinement period & Disagree & 72 & 10.6 & & & \\
\hline & Neutral & 85 & 12.5 & & & \\
\hline & Agreed & 250 & 36.9 & & & \\
\hline & Totally agree & 244 & 36.0 & & & \\
\hline
\end{tabular}


Table 4 Descriptive statistics of the mobility impact of COVID-19 during the first confinement of the epidemic in Algeria $(n=678)$

\begin{tabular}{|c|c|c|c|c|c|c|}
\hline \multirow[t]{2}{*}{ Items } & \multicolumn{3}{|l|}{$\mathrm{N}=678$} & \multirow[t]{2}{*}{ Mean (M) } & \multirow[t]{2}{*}{ Relative weight } & \multirow[t]{2}{*}{ Rating } \\
\hline & & $\mathrm{n}$ & $\%$ & & & \\
\hline \multirow[t]{5}{*}{ I find it easy to move around during the confinement period } & Not agree at all & 91 & 13.4 & \multirow[t]{5}{*}{2.93} & \multirow[t]{5}{*}{58.60} & \multirow[t]{5}{*}{04} \\
\hline & Disagree & 190 & 28.0 & & & \\
\hline & Neutral & 137 & 20.2 & & & \\
\hline & Agreed & 196 & 28.9 & & & \\
\hline & Totally agree & 64 & 9.4 & & & \\
\hline \multirow[t]{5}{*}{ Individual transportation is available during confinement } & Not agree at all & 113 & 16.7 & \multirow[t]{5}{*}{3.06} & \multirow[t]{5}{*}{61.20} & \multirow[t]{5}{*}{03} \\
\hline & Disagree & 133 & 19.6 & & & \\
\hline & Neutral & 121 & 17.8 & & & \\
\hline & Agreed & 225 & 33.2 & & & \\
\hline & Totally agree & 86 & 12.7 & & & \\
\hline \multirow[t]{5}{*}{ Minimum transportation service is available during the confinement period } & Not agree at all & 155 & 22.9 & \multirow[t]{5}{*}{2.49} & \multirow[t]{5}{*}{49.80} & \multirow[t]{5}{*}{06} \\
\hline & Disagree & 208 & 30.7 & & & \\
\hline & Neutral & 175 & 25.8 & & & \\
\hline & Agreed & 106 & 15.6 & & & \\
\hline & Totally agree & 34 & 5.0 & & & \\
\hline \multirow[t]{5}{*}{ I have to travel a lot to buy the necessary things during confinement } & Not agree at all & 115 & 17.0 & \multirow[t]{5}{*}{2.46} & \multirow[t]{5}{*}{49.20} & \multirow[t]{5}{*}{07} \\
\hline & Disagree & 264 & 38.9 & & & \\
\hline & Neutral & 186 & 27.4 & & & \\
\hline & Agreed & 99 & 14.6 & & & \\
\hline & Totally agree & 14 & 2.1 & & & \\
\hline \multirow[t]{5}{*}{ I prefer to use a bike to move around during confinement } & Not agree at all & 110 & 16.2 & \multirow[t]{5}{*}{2.68} & \multirow[t]{5}{*}{53.60} & \multirow[t]{5}{*}{05} \\
\hline & Disagree & 177 & 26.1 & & & \\
\hline & Neutral & 254 & 37.5 & & & \\
\hline & Agreed & 93 & 13.7 & & & \\
\hline & Totally agree & 44 & 6.5 & & & \\
\hline \multirow[t]{5}{*}{ I prefer to walk on foot when moving during the confinement period } & Not agree at all & 81 & 11.9 & \multirow[t]{5}{*}{3.28} & 65.60 & 02 \\
\hline & Disagree & 115 & 17.0 & & & \\
\hline & Neutral & 103 & 15.2 & & & \\
\hline & Agreed & 289 & 42.6 & & & \\
\hline & Totally agree & 90 & 13.3 & & & \\
\hline I respect the ban on moving at night during confinement & Not agree at all & 23 & 3.4 & 4.33 & 86.60 & 01 \\
\hline & Disagree & 21 & 3.1 & & & \\
\hline & Neutral & 43 & 6.3 & & & \\
\hline & Agreed & 214 & 31.6 & & & \\
\hline & Totally agree & 377 & 55.6 & & & \\
\hline
\end{tabular}

\section{The difference in the social impact of COVID-19 ac- cording to the gender variable}

In order to answer this research question, we needed to compare the male/female means in the social impact variable, and then use an independent $\mathrm{T}$-test to compare the means between men and women in the sample.

The data in Table 5 indicate that there is no significant difference in the mean scores of the social impact of confinement during the coronavirus disease epidemic in Algeria between men $(M=44.3443)$ and women $(M=44.0330)$. However, when analyzing the differences in the items of this dimension, the T-test for the independent sample revealed certain significant differences as follows:

- The difficulty of staying at home during the period of confinement between men $(\mathrm{M}=3.44)$ and women $(\mathrm{M}=$ 2.98), because men spend most of the time outside the home, unlike women who are more closely related to the home and its obligations in daily life.

- The difficulty in controlling children during confinement between men ( $\mathrm{M}=3.72)$ and women $(\mathrm{M}=3.55)$, because the control of children worries most men, and especially within the boundaries of the house with a very limited ability to play to vent the children's energy throughout the day, which leads to a boring daily routine. This affects their unwanted behavior inside the house.

- The avoidance of family visits in the period of confinement between men $(M=4.54)$ and women $(M=4.74)$; women are more closely linked and involved in frequent family visits, and therefore they are more aware of the risks to their health and that of their families.

- The result for refusal to attend funerals during the confinement period for men $(M=4.16)$ and women $(M=$ 4.45) shows that women are more aware of avoiding gatherings, including funerals.

- Family dialogue during the period of confinement between men $(M=4.04)$ and women $(M=4.19)$ indicates that women are more interested and embodied in family dialogue. In fact, they are a driving factor in family dialogue between the different members of the family.

- The results regarding the limited space of the house during the period of confinement between men $(\mathrm{M}=3.15)$ and women $(\mathrm{M}=2.91)$ indicate that men are more sensitive to tight housing, particularly the inability to control children, and thus men aspire to a spacious space outside the house in social life. 
Table 5 The different social impacts of COVID-19 between men and women in Algeria during the first confinement of the epidemic $(n=678)$

\begin{tabular}{|c|c|c|c|c|c|c|}
\hline \multirow[t]{2}{*}{ Items } & \multicolumn{2}{|l|}{ Men (405) } & \multicolumn{2}{|c|}{ Women (273) } & \multirow[t]{2}{*}{$\mathrm{T}$} & \multirow[t]{2}{*}{ Sig } \\
\hline & Mean $(\mathrm{M})$ & $\begin{array}{l}\text { Standard } \\
\text { deviation }\end{array}$ & Mean (M) & $\begin{array}{l}\text { Standard } \\
\text { deviation }\end{array}$ & & \\
\hline I find it difficult to stay in home confinement & 3.44 & 1.295 & 2.98 & 1.401 & 4.381 & 0.000 \\
\hline Controlling children is difficult during confinement & 3.72 & 1.065 & 3.55 & 1.137 & 1.989 & 0.047 \\
\hline $\begin{array}{l}\text { In confinement, I communicate with my family } \\
\text { members according to the instructions of the preventive distance }\end{array}$ & 3.19 & 1.189 & 3.37 & 1.288 & -1.848 & 0.065 \\
\hline We avoid family visits & 4.54 & 0.631 & 4.74 & 0.552 & -4.374 & 0.000 \\
\hline In confinement, I refuse to attend a funeral & 4.16 & 1.097 & 4.45 & 0.857 & -3.933 & 0.000 \\
\hline I find it easy to buy what I need in my daily life & 3.56 & 1.194 & 3.47 & 1.166 & 0.963 & 0.336 \\
\hline In confinement, I play sports at home & 3.44 & 1.167 & 3.36 & 1.243 & 0.897 & 0.370 \\
\hline I find that the diet is beneficial during the period of confinement & 3.81 & 0.999 & 3.76 & 1.175 & 0.610 & 0.542 \\
\hline Family dialogue prevails at home during the confinement period & 4.04 & 0.846 & 4.19 & 0.937 & -2.121 & 0.034 \\
\hline Limited space in the house bothers me during the confinement period & 3.15 & 1.317 & 2.91 & 1.267 & 2.360 & 0.019 \\
\hline $\begin{array}{l}\text { It is difficult to organize fun games } \\
\text { for children at home during the confinement period }\end{array}$ & 3.39 & 1.108 & 3.38 & 1.167 & 0.103 & 0.918 \\
\hline $\begin{array}{l}\text { Using smartphones is the best way to pass } \\
\text { the time during the confinement period }\end{array}$ & 3.92 & 1.116 & 3.88 & 1.135 & 0.378 & 0.705 \\
\hline Total (social impact) & 44.3443 & 4.50779 & 44.0330 & 5.81413 & 0.746 & 0.456 \\
\hline
\end{tabular}

\section{The difference in the mobility impact because of COVID-19 according to the gender variable}

In order to answer this research question, we compared the mean men/women responses regarding the mobility impact variable, and then an independent T-test was used to compare the means between men and women in the sample.

Table 6 shows the significant differences in the mean scores regarding the impact of mobility during the confinement of COVID-19 in Algeria between men and women, and the T-test for the independent sample revealed that:
- The ease of moving during the period of confinement between men $(\mathrm{M}=3.11)$ and women $(\mathrm{M}=2.6)$ is more significant in favor of men. This result reflects the tendency of men to move to buy goods for daily needs to preserve their families.

- The results regarding moving to buy the necessary things during confinement between men $(\mathrm{M}=2.63)$ and women $(\mathrm{M}=2.21)$ confirm the above that men are usually responsible for frequent trips outside the house for supplies.

- The use of bicycles for movement during confinement between men $(\mathrm{M}=2.78)$ and women $(\mathrm{M}=2.53)$ clearly

Table 6 The different mobility impacts of COVID-19 between men and women in Algeria during the first confinement of the epidemic $(n=678)$

\begin{tabular}{|c|c|c|c|c|c|c|}
\hline \multirow[t]{2}{*}{ Items } & \multicolumn{2}{|c|}{ Men (405) } & \multicolumn{2}{|c|}{ Women (273) } & \multirow[t]{2}{*}{$\mathrm{T}$} & \multirow[t]{2}{*}{ Sig } \\
\hline & $\begin{array}{l}\text { Mean } \\
(\mathrm{M})\end{array}$ & $\begin{array}{l}\text { Standard } \\
\text { deviation }\end{array}$ & $\begin{array}{l}\text { Mean } \\
\text { (M) }\end{array}$ & $\begin{array}{l}\text { Standard } \\
\text { deviation }\end{array}$ & & \\
\hline I find it easy to move around during the confinement period & 3.11 & 1.185 & 2.66 & 1.217 & 4.750 & 0.000 \\
\hline Individual transportation is available during confinement & 3.07 & 1.337 & 3.04 & 1.257 & 0.318 & 0.751 \\
\hline Minimum transportation service is available during the confinement period & 2.44 & 1.177 & 2.57 & 1.106 & -1.466 & 0.143 \\
\hline I must travel a lot to buy the necessary things during confinement & 2.63 & 0.988 & 2.21 & 0.972 & 5.441 & 0.000 \\
\hline I prefer to use a bike to move around during confinement & 2.78 & 1.125 & 2.53 & 1.043 & 2.941 & 0.003 \\
\hline I prefer to walk on foot when moving during the confinement period & 3.39 & 1.225 & 3.13 & 1.239 & 2.629 & 0.009 \\
\hline I respect the ban on moving at night during confinement & 4.22 & 1.072 & 4.48 & 0.772 & -3.433 & 0.001 \\
\hline Total (mobility impact) & 21.6370 & 3.55844 & 20.6264 & 3.37589 & 3.702 & 0.000 \\
\hline
\end{tabular}


shows that movement by bicycle remains limited to men in this society due to social traditions.

- The movement on foot during the period of confinement between men $(M=3.39)$ and women $(M=3.13)$ highlights that men often leave the house, and they prefer to travel by foot more than women.

- The results regarding compliance with the ban on movement at night during confinement between men $(\mathrm{M}=4.22)$ and women $(M=4.48)$ show that women are more respectful of the instructions not to move at night than men. Certainly, the women's movement generally decreases at night, and in addition, they are respectful of laws and regulations.

Indeed, the results showed significant differences in the mobility impact between men $(M=21.6370)$ and women $(M=20.6264)$ in favor of men.

\section{The difference in social impact and mobility regarding COVID-19 according to the family situation (single, married)}

According to the results presented in Table 7 , there is no significant difference in the mean scores of social impact and mobility during the confinement because of COVID-19 in Algeria between the unmarried and the married; the T-test for the independent sample revealed that single and married people are affected at the same levels due to the confinement implemented because of COVID-19 in Algeria.

\section{Discussion}

The results of the study of the social impact and mobility of total and partial confinement due to COVID-19 in Algeria, during the first 3 weeks (from March 23 to April 12, 2020), show the existence of a positive and statistically significant correlation between the variable of social effects and the effects on mobility and transport $(r=0.229)$ with an error level equal to $(0.01)$. This means that road interactions and mobility are only part of the social interactions linked to everyday life. The need to travel is often present among the population for various reasons.
In terms of social impact, the results suggest that $95.1 \%$ of respondents avoid family visits to limit the risk of infection, knowing that the confinement measure shows that the authorities consider the situation serious and is likely to worsen (Rubin and Wessely 2020), and they are convinced that distancing is the means of prevention and that people carrying the virus can infect others by respiratory droplets as well as by direct contact (Fan et al. 2020). We find that $80.50 \%$ of respondents avoid attending funerals as long as they know the risks of gatherings and also because of the bans imposed by the authorities. In addition, it is known that China managed to contain the spread of the disease for 2 months by total confinement (Verity et al. 2020).

During these first 3 weeks of confinement, $85.5 \%$ of respondents say that they spend a considerable amount of time talking to each other as a family. In contrast, $72.9 \%$ of respondents find smartphones as the best way to pass the time and as well communicate with family and friends because it is essential during confinements and quarantines (Brooks et al. 2020).

Of respondents, $66.6 \%$ find the diet during the confinement period beneficial. Controlling children during this period is considered difficult by $60.7 \%$ of respondents, especially because people are used to placing their children in daycare centers, which are closed during this confinement. In addition, $46 \%$ of respondents say that it is difficult to organize fun games for children, which further complicates daily life for this part of the sample.

Of respondents, $63.3 \%$ find it easy to buy the goods necessary for daily life because containment measures allow certain types of commerce to open in different places in cities.

Of respondents, $57 \%$ say that they play sports during this first period of confinement. The latter are aware that sporting activity is important for staying in good physical and mental health, since it has been shown in previous research, such as that on the psychosocial effects of the Ebola epidemic, that the magnitude of the psychosocial effects on individuals and society appears even at the international level when an epidemic appears (Van Bortel et al. 2016). For communication with family members, we find that $47.9 \%$ of respondents follow the instructions of the preventive distance, which indicates that this category of the population is aware of why it is necessary.
Table 7 The differences in the social impact and mobility between single and married people in Algeria during the first confinement of the epidemic $(\mathrm{n}=$ 678)

\begin{tabular}{|c|c|c|c|c|c|c|}
\hline \multirow[t]{2}{*}{ Items } & \multicolumn{2}{|c|}{ Singles (408) } & \multicolumn{2}{|c|}{ Married (270) } & \multirow[t]{2}{*}{$\mathrm{T}$} & \multirow[t]{2}{*}{ Sig } \\
\hline & Mean(M) & Standard deviation & Mean (M) & Standard deviation & & \\
\hline Social impact & 21.3235 & 3.42677 & 21.0889 & 3.65515 & 0.850 & 0.396 \\
\hline Mobility impact & 44.1299 & 5.20634 & 44.3536 & 4.86991 & -0.562 & 0.574 \\
\hline
\end{tabular}


Among the respondents, $52.3 \%$ find it difficult to stay at home; this seems logical since the 3 weeks of confinement cause negative effects on individuals because confinement causes a slowdown in life and sometimes blockages, which can lead to psychological disturbances. Symptoms are marked by depression, panic, and behavioral disorders (Sood 2020).

The results on the impact of confinement on mobility showed that $87.2 \%$ of respondents respect the ban on moving at night, while only $6.5 \%$ of respondents do not comply with this ban. This is linked to the new regulatory texts that introduce this kind of night outing as well as the guidelines taken to minimize human contact to protect the population in many countries (Vellingiri et al. 2020).

It is reported that $55.9 \%$ of respondents prefer to travel on foot during outings for purchases during the confinement period. This mode of travel is linked to the presence of shops near residents and the desire to make walking a means of physical activity. In addition, avoiding crowded transportation grants more prevention because it is always difficult to fight against this disease of unknown origin and mysterious biological characteristics (Xie and Chen 2020).

Among the other $45.9 \%$ of respondents who find that individual means of transport are available during confinement, it is found that many people outside the city center take their means of personal transport and carry people with them by car. The results show, among other things, that $38.3 \%$ of respondents find it easy to move during total and partial confinement. For the use of a bicycle, the results show that $20.2 \%$ of respondents opt for this mode of travel. This is linked to the absence of cycle paths and a strategy to encourage the use of bicycles in Algeria.

Note that $20.6 \%$ of those surveyed find transport available because they either use their own means or travel with their friends and neighbors who have individual means of transport. It is also noted that the officials of certain services have means of transport to ensure the movement of their staff. In addition, $16.7 \%$ of respondents travel often to buy the necessary products during confinement. This category of people either lives on the outskirts of cities or searches for low-cost products, which pushes them to do a considerable amount of shopping while on the move.

For the difference in the social impact of COVID-19 according to the gender variable, the results show that there is no significant difference in the average social impact of confinement in Algeria between men $\overline{(X}=44.3443)$ and women $\overline{(X}=$ 44.0330). However, the analysis of the differences according to the items through the T-test reveals some significant differences, as mentioned in Table 5.

The results showed significant differences in the impact of mobility between men $\overline{\mathrm{X}}=21.6370)$ and women $\bar{X}=20.6264)$ in favor of men, who spend a considerable amount of their time outside the home. We also note that single and married people are affected at the same levels by the effects of social impact and mobility during this first COVID-19 confinement, which can be explained by the nature of the life of families in Algeria.

\section{Conclusion}

The spread of the COVID-19 pandemic continues to affect people in many countries. This study aimed to quickly assess, in Algeria, the impact of total and partial confinement on the social aspects and that of mobility during a period of 3 weeks (March 23 to April 12, 2020) using an online questionnaire.

The results showed that road interactions and mobility are only part of the social interactions linked to daily life, since the need to move is often present for different reasons among the population. This study showed significant impacts on the social aspect linked to travel, family relationships, and sports activities. Also, there are significant impacts on the mobility of people, particularly on individual means and modes of travel as well as the facilities of mobility during this period of confinement. The data showed the absence of a significant difference between men and women for the social impact of confinement as a whole; however, some differences are visible for certain items.

A significant difference in the impact of mobility between men and women is observed in favor of men. Among other things, single and married people are affected at the same levels by social impact and mobility. The results of this study are not to be generalized over the entire Algerian population, but can help the authorities to mitigate the impacts of confinement on the population through actions to remotely help families to better take care of their children at home.

For mobility, it is important to encourage the use of bicycles by creating secure temporary cycle paths because the bicycle guarantees a protective distance. The media should also encourage people who are confined to participate in adapted physical activities at home in order to stay healthy during confinement, since only $57 \%$ of the population surveyed takes part in sports.

The current study can be developed to study the effects of confinement on quality of life and relate them to risk behaviors associated with the COVID-19 pandemic.

Contributions All authors contributed to the study conception and design. Material preparation, data collection and analysis were performed by Saad Eddine Boutebal and Azzeddine Madani. The first draft of the manuscript was written by Saad Eddine Boutebal, Azzeddine Madani and Christopher Robin Bryant, and all authors commented on previous versions of the manuscript. All authors read and approved the final manuscript.

Funding This research did not receive any specific grant from funding agencies in the public, commercial, or not-for-profit sectors. 


\section{Compliance with ethical standards}

Conflict of interest The authors declare that they have no conflict of interest.

Ethics approval All procedures performed in this study involving human participants were in accordance with the ethical standards of the institutional and/or national research committee and with the 1964 Helsinki Declaration and its later amendments or comparable ethical standards.

Statement on participant consent Participants were invited to participate in the online survey, they had the choice of answering or not. The introduction to the survey informed that this is part of academic research. All responses were anonymous.

\section{References}

Bailly A (2020) COVID-19 Chroniques d'un géographe de la santé. Consultation francophone sur les impacts sociaux et spatiaux du Covid 19 (CORTE). https://codevirusshs.wixsite.com/website/ news-2. Accessed April 142020

Brooks SK, Webster RK, Smith LE, Woodland L, Wessely S, Greenberg N, Rubin GJ (2020) The psychological impact of quarantine and how to reduce it: rapid review of the evidence. Lancet 395(10227):912-920. https://doi.org/10.1016/S0140-6736(20) 30460-8

Fan C, Liu L, Guo W, Yang A, Ye C, Jilili M, Ren M, Xu P, Long H, Wang Y (2020) Prediction of epidemic spread of the 2019 novel coronavirus driven by spring festival transportation in China: a population-based study. Int J Environ Res Public Health 17(5): 1679. https://doi.org/10.3390/ijerph17051679

Guan WJ, Ni ZY, Hu Y, Liang WH, Ou CQ, He JX et al (2020) Clinical characteristics of coronavirus disease 2019 in China. N Engl J Med 382(18):1708-1720. https://doi.org/10.1056/NEJMoa2002032

Madani A (2020) Vitesse de propagation du COVID-19, L'Algérie sera-telle comme les pays les plus touchés de l'Europe? Consultation francophone sur les impacts sociaux et spatiaux du Covid 19 (CORTE). https://codevirusshs.wixsite.com/website. Accessed on 14 April 2020

MSPRH (2020a). http://www.sante.gov.dz/communiques/82documentation/612-suivi-quotidien-du-coronavirus-covid-19mardi-21-avril-2020.html. Accessed Apr 212020
MSPRH (2020b). http://www.sante.gov.dz/coronavirus/coronavirus2019/82-documentation/531-point-de-situation.html. Accessed Apr 212020

Munster VJ, Koopmans M, van Doremalen N, van Riel D, de Wit E (2020) A novel coronavirus emerging in China - key questions for impact assessment. N Engl J Med 382(8):692-694. https://doi.org/ 10.1056/NEJMp2000929

Rubin GJ, Wessely S (2020) The psychological effects of quarantining a city. BMJ 368:m313. https://doi.org/10.1136/bmj.m313

Sohrabi C, Alsafi Z, O'Neill N, Khan M, Kerwan A, Al-Jabir A, Iosifidis C, Agha R (2020) World Health Organization declares global emergency: a review of the 2019 novel coronavirus (COVID-19). Int J Surg 76:71-76. https://doi.org/10.1016/j.ijsu.2020.02.034

Sood S (2020) Psychological effects of the coronavirus disease-2019 pandemic. Res Humanities Med Educ 7:23-26 https://www.rhime. in/ojs/index.php/rhime/article/view/264

Van Bortel T, Basnayake A, Wurie F, Jambai M, Koroma AS, Muana AT, Hann K, Eaton J, Martin S, Nellums LB (2016) Psychosocial effects of an Ebola outbreak at individual, community and international levels. Bull World Health Organiz 94(3):210-214. https://doi. org/10.2471/BLT.15.158543

Vellingiri B, Jayaramayya K, Iyer M, Narayanasamy A, Govindasamy V, Giridharan B, Ganesan S, Venugopal A et al (2020) COVID-19: a promising cure for the global panic. Sci Total Environ 725:138277. https://doi.org/10.1016/j.scitotenv.2020.138277

Verity R, Okell LC, Dorigatti I, Winskill P, Whittaker C, Imai N et al (2020) Estimates of the severity of coronavirus disease 2019: a model-based analysis. Lancet Infect Dis 20(6):669-677. https:// doi.org/10.1016/S1473-3099(20)30243-7

Wang C, Pan R, Wan X, Tan Y, Xu L, Ho CS, Ho RC (2020) Immediate psychological responses and associated factors during the initial stage of the 2019 coronavirus disease (COVID-19) epidemic among the general population in China. Int J Environ Res Public Health 17(5):1729. https://doi.org/10.3390/ijerph17051729

Who (2020) Coronavirus disease (COVID-19) weekly epidemiological update and weekly operational update. https://www.who.int/ emergencies/diseases/novel-coronavirus-2019/situation-reports. Accessed April 142020

Xie M, Chen Q (2020) Insight into 2019 novel coronavirus - an updated intrim review and lessons from SARS-CoV and MERS-CoV. Int J Infect Diseases 94:119-124. https://doi.org/10.1016/j.ijid.2020.03. 071

Publisher's note Springer Nature remains neutral with regard to jurisdictional claims in published maps and institutional affiliations. 